\title{
Studies of Molecular Variation Sources Using RAPD and SSR Markers in Two Garlic Clones
}

\author{
Gehan M. Anwar*, Mohamad A-H. Mahmoud, Abdeltawab M. Ata, Ragab A-K. Ragab, Hanaa S. H. Bakry \\ Department of Genetics, Faculty of Agriculture, Minia University, 61519 Minia, Egypt \\ * Correspondence: gehan_ma@yahoo.com; Tel: +2 01008998651; Fax: +20 862362182
}

\section{Article information}

Received: 29 February 2020

Revised: 4 May 2020

Accepted: 4 May 2020

\section{Key words}

Garlic

Cloves

Genetic diversity

Polymorphism

RAPD

SSR markers

\begin{abstract}
The present work aimed at study genetic diversity and the sources of molecular variation between the individual cloves of two garlic clones with different molecular markers, RAPD and SSR. Three bulbs of two garlic clones (Egaseed1 and Balady) were germinated (three individual cloves of each bulb). The total genomic DNA was extracted from the young leaves. Ten RAPD and fifteen SSR primers were used and the data were statistically analyzed. Fifty-seven bands (including 4 unique and 53 polymorphic) were totally generated and there were no monomorphic bands from ten RAPD primers. Two unique bands were detected with KO3 and KO6 primers (433 and 417 bp, respectively), likewise, two unique bands of 124 and 188 bp were detected with K10 RAPD primer in Egaseed1 clone. Thirteen SSR primers produced 45 DNA fragments. Out of them, 12 were monomorphic and the remaining were polymorphic. Different molecular markers could be used to evaluate genetic diversity and confirm the molecular differences between the cloves derived from the same bulb and the differentiated nature of garlic. In addition, it defines the importance of using molecular markers to evaluate different garlic clones.
\end{abstract}

\section{Introduction}

The value of garlic as a crop has been recognized from long ancient times. It has been cultivated for over 50 centuries and used as food, condiment and medicine by many civilizations in Asia and Mediterranean region [1]. Garlic (Allium sativum $\mathrm{L}$.) is a diploid $(2 \mathrm{n}=2 \mathrm{x}=16)$ herbaceous plant that belongs to the family Liliaceae and is closely related to other species, including onion, leek, chives, and shallots [2]. Garlic has one of the largest genomes among cultivated crops by DNA amount of $32.7 \mathrm{pg}$. per $2 \mathrm{C}$ nucleus. For centuries, garlic has been clonally propagated, however, genetic studies revealed the presence of considerable genetic diversity among the garlic clones [3-5]. In spite of phenotypic flexibility and the occurrence of mutations, the identification and systematic classification of garlic are difficult [6-10]. Depending on intraspecific diversity resulted from isozyme and RAPD analysis [11], garlic clones from the old world were classified into four subgroups; the sativum group from the Mediterranean, the ophioscorodon from middle and eastern Europe, the longicuspis from Central Asia and the subtropical group from southern Asia. The longicuspis group includes A. longicuspis and the East Asian subgroup pekinense. Clones from this group are bolting type and have coiling scapes and some produce, to a varying extent, fertile flowers.

DNA polymorphisms are the markers of choice for identification and characterization of the whole garlic genome and they are not subjected to environmental modifications [12]. Several molecular markers are available for the investigation of garlic genetic diversity. For instance, RAPD [13], SSR [14-17],
AFLP [18, 19] and ISSR [20] are the most common markers. Numerous investigators have successfully employed RAPD for taxonomic studies and classification $[11,21]$ as well as cultivar identification [22]; genotypic screening [23]; tissue culture [24] and breeding programmers [25]. The present work aimed at study genetic diversity and the sources of molecular variation between the individual cloves of two garlic (Allium sativum) clones by using two different molecular markers, RAPD and SSR.

\section{MATERIALS AND METHODS}

\subsection{Plant materials}

In the present work, bulbs of two garlic (Allium sativum L.) clones called Balady or Egyptian (White) and Egaseed1 (purple) were kindly obtained from Seds Agriculture Research Station, Agriculture Research Center (ARC). The experiment was carried out at the Genetic Department, Faculty of Agriculture, Minia University, Egypt. This research was conducted from September, 2018 to April, 2019.

\subsection{Genomic DNA isolation}

Three bulbs of each garlic clones (Egaseed1 and Balady) were randomly selected and three individual cloves of each bulb were germinated. Total genomic DNA was extracted from 200 $\mathrm{mg}$ of the young shoot leaves of each clove. Samples were grinded in liquid nitrogen to fine powder then DNA was extracted using Cornel extraction buffer $(500 \mathrm{mM} \mathrm{NaCl}, 100$ $\mathrm{mM}$ Tris- $\mathrm{HCl}, \mathrm{PH} 8.0,50 \mathrm{mM}$ EDTA and $0.84 \%$ SDS). The re- 
suspended DNA was verified with $1 \%$ agarose gel electrophoresis. Concentration and purity of extracted DNA were determined via spectrophotometer set at 260 and $280 \mathrm{~nm}$ absorbance [26].

\subsection{RAPD - PCR markers}

Ten common RAPD primers (Table 1) were used for screening the genetic diversity of two studied garlic clones (Balady and Egased1). DNA samples of nine individual garlic cloves of each clone (three different head/bulb, three cloves of each head) were subjected to PCR against the ten random primers. Ten primers of 10-base long oligonucleotides of arbitrary sequence were used as shown in (Table 1).

\subsection{RAPD PCR reaction contents}

RAPD PCR reactions were carried out according to Anwar [27], with some modifications. Template DNA, the appropriate primer and 2X PCR Master Mix (0.05 units/ $\mu$ l Taq DNA polymerase; $4 \mathrm{mM} \mathrm{MgCl}_{2} ; 0.4 \mathrm{mM}$ of each dNTPs (dATP, dGTP, dCTP, dTTP) were used for achieving PCR reaction. The amplification program is consisting of an initial denaturing step for $4 \mathrm{~min} / 94{ }^{\circ} \mathrm{C}$; followed by 40 cycles of denaturation $(1 \mathrm{~min}$ $\left.194{ }^{\circ} \mathrm{C}\right)$, annealing $\left(1 \mathrm{~min} / 36{ }^{\circ} \mathrm{C}\right)$, and extension $\left(2 \mathrm{~min} / 72{ }^{\circ} \mathrm{C}\right)$ and a final elongation step for $5 \mathrm{~min} / 72{ }^{\circ} \mathrm{C}$.

\subsection{PCR conditions for SSR analysis}

Fifteen microsatellite primers, particularly developed for garlic (Allium sativum) [28] were employed to perform SSR analysis among the individual plants germinated from individual cloves. The characteristics of the 15 microsatellite primers are shown in (Table 2). The amplification program used is described by Ma et al. [29].

Following PCR reactions of the RAPD and SSR markers, $15 \mu 1$ of each sample were mixed with $5 \mu$ of DNA loading buffer

Table 1: The nucleotide sequence and the GC ratio of the used primers in RAPD-PCR

\begin{tabular}{cccc}
\hline No. & primers & Sequence $\mathbf{5}$-3 & GC \\
\hline 1 & K-02 & 60.0 \\
2 & K-03 & GTC TCC GCA A & 60.0 \\
3 & K-04 & CCA GCT TAG G & 60.0 \\
4 & K-06 & CAC CTT TCC C & 60.0 \\
5 & K-07 & AGC GAG CAA G & 60.0 \\
6 & K-08 & GAA CAC TGG G & 60.0 \\
7 & K-10 & GTG CAA CGT G & 60.0 \\
8 & L-01 & GGC ATG ACC T & 60.0 \\
9 & M-02 & GTC TCC GCA A & 60.0 \\
10 & M-04 & CGG CCC AAA C & 60.0 \\
\hline
\end{tabular}

Table 2: Forward and reverse sequence, repeat motif, annealing temperature, size of the original fragment, and GenBank accession number of the 15 microsatellite primers developed for Allium sativum.

\begin{tabular}{|c|c|c|c|c|c|}
\hline Loci & Primer sequence $\left(5^{\prime}-3^{\prime}\right)$ & $\begin{array}{c}\text { Repeat } \\
\text { motif }\end{array}$ & $\begin{array}{c}T \mathbf{a} \\
\left({ }^{\circ} \mathbf{C}\right)\end{array}$ & $\begin{array}{l}\text { Allele size } \\
\text { (bp) }\end{array}$ & $\begin{array}{c}\text { GenBank } \\
\text { Accession No. }\end{array}$ \\
\hline Asa04 & $\begin{array}{l}\text { F: AGACTTTTGGAGGCTAGGGC } \\
\text { R: CCCTGGTCTCTTTCAACCAA }\end{array}$ & $(\mathrm{TCC})_{5}(\mathrm{TCC})_{4}(\mathrm{TCC})_{5}$ & 54 & 264 & JN084085 \\
\hline Asa06 & $\begin{array}{l}\text { F: GGGGTGTTACATTCTCCCCT } \\
\text { R: ACCGCCTGATTTTGCATTAG }\end{array}$ & $(\mathrm{TG})_{5}$ & 57 & 192 & JN084086 \\
\hline Asa07 & $\begin{array}{l}\text { F: CTCGGAACCAACCAGCATA } \\
\text { R: CCCAAACAAGGTAGGTCAGC }\end{array}$ & $(\mathrm{TG})_{7}$ & 58 & $229-235$ & JN084087 \\
\hline Asa08 & $\begin{array}{l}\text { F: TGATTGAAACGAATCCCACA } \\
\text { R: GGGGGTTACCTGAACCTGTTA }\end{array}$ & $(\mathrm{GT})_{8}$ & 56 & $209-257$ & JN084088 \\
\hline Asa10 & $\begin{array}{l}\text { F: TTGTTGTTCTGCCATTTT } \\
\text { R: GATCTAAGCCGAGAGAAA } \\
\end{array}$ & $(\mathrm{AC})_{7}$ & 48 & $225-239$ & JN084089 \\
\hline Asa14 & $\begin{array}{l}\text { F: TCTATCTCGCTTCTCAGGGG } \\
\text { R: GCTGACAGAAGTAGTCTTTCC }\end{array}$ & $(\mathrm{GT})_{7}$ & 48 & $220-234$ & JN084090 \\
\hline Asa16 & $\begin{array}{l}\text { F: CACGACTTTTCCTCCCATTT } \\
\text { R: GCTAATGTTCATGTCCCCAGT }\end{array}$ & $(\mathrm{TG})_{5} \mathrm{C}(\mathrm{GT})_{6}$ & 48 & $148-154$ & JN084091 \\
\hline Asa18 & $\begin{array}{l}\text { F: TCAAGCTCCTCCAAGTGTCC } \\
\text { R: TCGGGATATGACAGCATTTG }\end{array}$ & $(\mathrm{TG})_{8}$ & 45 & $254-264$ & JN084093 \\
\hline Asa20 & $\begin{array}{l}\text { F: GAAGCAGCAAAGATCCAAGC } \\
\text { R: CGTGCAGAACTTAACCTT }\end{array}$ & $(G)_{12}$ & 48 & 260 & JN084094 \\
\hline Asa23 & $\begin{array}{l}\text { F: TGGAGGGGGAAAAAGGATAG } \\
\text { R: TGTGAAGCAAGTGGGATCAA }\end{array}$ & $(\mathrm{GA})_{5}$ & 55 & 271 & JN084095 \\
\hline Asa24 & $\begin{array}{l}\text { F: TTGTTGTGCCGAGTTCCATA } \\
\text { R: CAGCAATTTACCAAAGCCAAG }\end{array}$ & $(\mathrm{GT})_{4}(\mathrm{GT})_{3}(\mathrm{GT})_{5}$ & 48 & $149-161$ & JN084096 \\
\hline Asa25 & $\begin{array}{l}\text { F: GCACTTCACTTTCCCCATTC } \\
\text { R: GGCGACGGTGAAGAGAGAG } \\
\end{array}$ & $(\mathrm{CT})_{3}(\mathrm{CT})_{27}$ & 51 & $117-127$ & JN084097 \\
\hline Asa27 & $\begin{array}{l}\text { F: GGGAGAGAATGGCTTGATTG } \\
\text { R: GGACAGCATCATCACCAC }\end{array}$ & $\left.(\mathrm{TC})_{17} \mathrm{TC}\right)_{5}$ & 55 & 127 & N084098 \\
\hline Asa31 & $\begin{array}{l}\text { F: CAGAGACTAGGGCGAATGG } \\
\text { R: ATGATGATGACGACGACGAG }\end{array}$ & $(\mathrm{CTT})_{7}$ & 50 & $237-243$ & JN084099 \\
\hline Asa59 & $\begin{array}{l}\text { F: CGCTTACTATGGGTGTGTGTC } \\
\text { R: CAAGTGGGAGACTGTTGGAG }\end{array}$ & $(\mathrm{ATCA})_{3}$ & 50 & 290 & JN084100 \\
\hline
\end{tabular}


and loaded onto $1.5 \%$ agarose gel electrophoresis. DNA fragment sizes were estimated according to the standard marker of 100-2000 bp ladder resolved in the same gel. Photography was done by using Gel Doc. (GBOX 230V).

\subsection{Statistical analysis}

Gel images were analyzed by using the free software GelAnalyzer3 [30] Molecular sizes of the amplified fragments, presence (1) or absence (0), frequencies, polymorphism type (either monomorphic or polymorphic) through samples, the mean frequency of band and the polymorphism percentage for each primer were determined.

\section{RESULTS}

\subsection{RAPD markers}

Total number of amplified fragments, number of unique and polymorphic bands as well as percentage of polymorphism obtained by 10 common RAPD primers of 18 cloves in both garlic clones (Egaseed1 and Balady) are shown in (Table 3). Fifty seven fragments (including four unique and fifty three polymorphic fragments) were totally produced. No monomorphic bands were detected from all studied samples. In addition, seven primers (K-02, K-04, K-07, K-08, L-01, M-02 and M-04) did not show unique bands. Data in (Table 3) showed that all studied RAPD products were polymorphic conferring a $100 \%$. Both K03 and K06 RAPD primers produced one unique band of 433 and $417 \mathrm{bp}$, respectively (Figure 1). Two unique bands of 124 and 188 bp were detected from Egaseed 1 by using K10 RAPD primer (Figure 1). The electrophoretic pattern of PCR products (Figure $1 \mathbf{a}_{1}$ and $\mathbf{a}_{2}$ ) generated by K-02 RAPD primer in Egaseed 1 and Balady cloves showed four DNA fragments with different amplicon sizes (211, 310, 410 and 491bp). Out of them, three bands with 211,310 and 410 bp were found in almost all cloves (5 cloves of Balady and 6 cloves of Egased1). The remaining $491 \mathrm{bp}$ amplified fragment was generated in cloves (lane number 1 through 7) of Balady accession. No amplified fragments were detected in four cloves (lane 1, 4, 7 and 9) of Egased1 and (8 and 9) of Balady.
Seven DNA fragments with different amplicon sizes ranged from 268 to 1259 bp were generated by using K-03 primer as shown in Figure $1\left(\mathbf{b}_{1}\right.$ and $\left.\mathbf{b}_{2}\right)$. Out of them, one fragment was unique with 433bp which found in one clove (lane number 5 of clone Egased1) while the other six fragments were polymorphic. K-03 primer could not generate any DNA fragment from clove numbers (1, 3 and 4) of the Egased1 genotype and clove numbers (1, 2, 4, 8 and 9) of the Balady genotype as shown in Figure 1 ( $\mathbf{b}_{1}$ and $\left.\mathbf{b}_{2}\right)$. K-04 primer generated four DNA polymorphic fragments $(188,270,511,845 \mathrm{bp})$ as shown in Figure 1 ( $\mathbf{c}_{\mathbf{1}}$ and $\left.\mathbf{c}_{2}\right)$. This primer failed to amplify any DNA fragments in sample number 4 of Egased1 and number 9 of Baldy. Eight amplified fragments were generated using K-06 RAPD primer as clarified in Figure $1\left(\mathbf{d}_{\mathbf{1}}\right.$ and $\left.\mathbf{d}_{\mathbf{2}}\right)$. Out of them, one (417 bp) was unique and the rest were seven polymorphic bands of 142, 165, 320, 420, 562, 777 and $884 \mathrm{bp}$. Three cloves (lanes 1, 8 and 9) of genotype Balady could not generate any DNA fragment upon using K-06 RAPD primer.

The electrophoretic pattern of PCR products generated by K-07 primer were seven polymorphic DNA fragments with different amplicon sizes ranged from 138 to 583 bp as shown in Figure 1 $\left(\mathbf{e}_{1}\right.$ and $\left.\mathbf{e}_{2}\right)$. This primer failed to amplify any regions in three cloves of Egased1 clone (lanes no. 1, 4, 9) two cloves Balady clone (lanes no. 8 and 9). Likewise, K-08 primer generated four (237, 481, 841 and 1598 bp) polymorphic DNA amplified fragments as shown in Figure 1 (f1 and f2). Three samples of genotype Egased 1 (lanes no. 1, 4 and 5) and two samples of genotype Balady (lanes no. 2 and 9) failed to generate any DNA fragment with the K-08 RAPD primer. Sample no. 7 of Egased 1 and no. 8 of the Balady genotype showed only one DNA fragment of $481 \mathrm{bp}$. The biggest fragment of $1598 \mathrm{bp}$ was found only in clove (no. 2 and 3) of clone Balady. Data in Tables (3) and Figure 1 ( $g_{1}$ and $\left.\mathbf{g}_{2}\right)$ indicated that seven DNA fragments were produced with different amplicon sizes ranged from 124 to 1204 bp by using K-10 primer. Two unique bands of amplicon sizes (124 and $188 \mathrm{bp}$ ) were clearly visible. The other bands (240, 296, 384, 496 and $1204 \mathrm{bp}$ ) were polymorphic conferring a $100 \%$ of polymorphism. Four polymorphic fragments $(0.157$, $0.264,0.366$, and $0.443 \mathrm{~kb}$ ) were generated by using L-01

Table 3: Total number of monomorphic, polymorphic and unique PCR fragments and percentage of polymorphism obtained by using 10 RAPD primers for studied garlic clones.

\begin{tabular}{cccccc}
\hline \multirow{2}{*}{ Primers } & Unique bands & \multicolumn{2}{c}{ Polymorphic bands } & \multirow{2}{*}{$\begin{array}{c}\text { Total number of } \\
\text { bands }\end{array}$} & Polymorphism (\%) \\
\cline { 3 - 4 } & & without Unique & with Unique & 4 & 100 \\
K-02 & 0 & 4 & 4 & 7 & 100 \\
K-03 & 1 & 4 & 4 & 8 & 100 \\
K-04 & 0 & 7 & 8 & 7 & 100 \\
K-06 & 1 & 7 & 7 & 4 & 100 \\
K-07 & 0 & 4 & 4 & 7 & 100 \\
K-08 & 0 & 5 & 7 & 4 & 100 \\
K-10 & 2 & 4 & 4 & 5 & 100 \\
L-01 & 0 & 5 & 5 & 7 & 100 \\
M02 & 0 & 7 & 7 & $\mathbf{5 7}$ & 100 \\
M04 & 0 & $\mathbf{5 3}$ & $\mathbf{5 7}$ & $\mathbf{1 0 0}$ \\
\hline Total & $\mathbf{4}$ & &
\end{tabular}



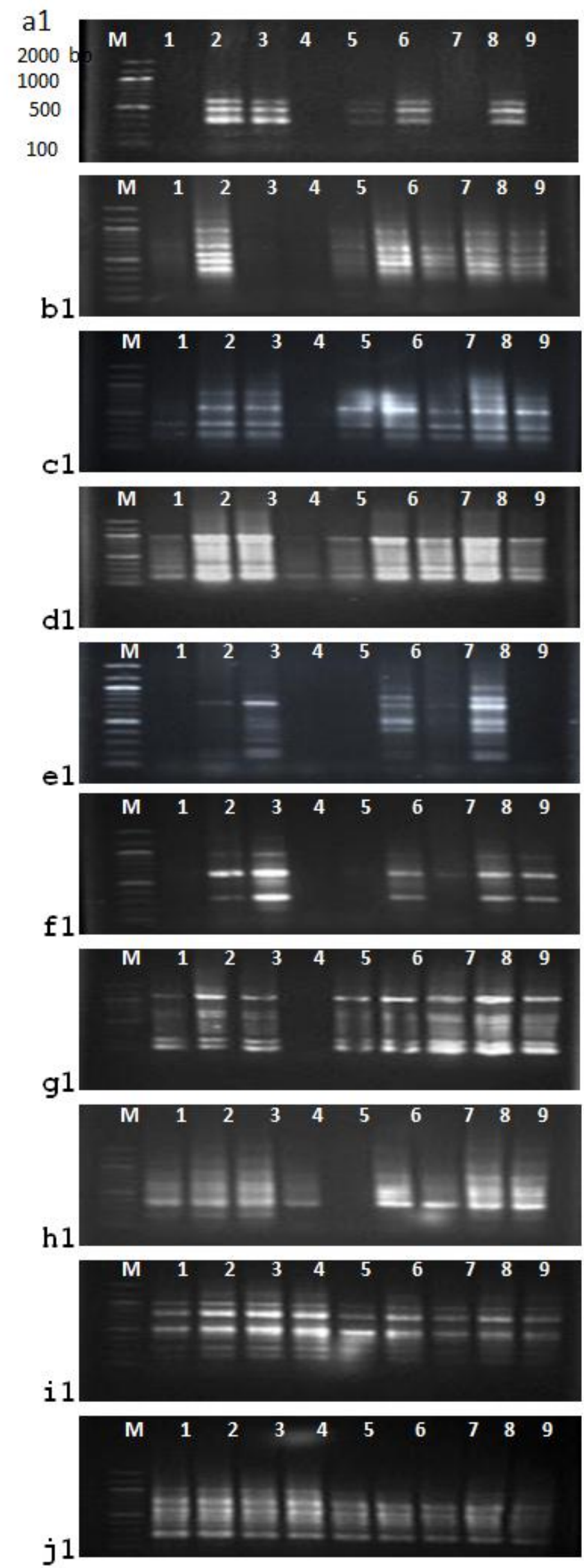
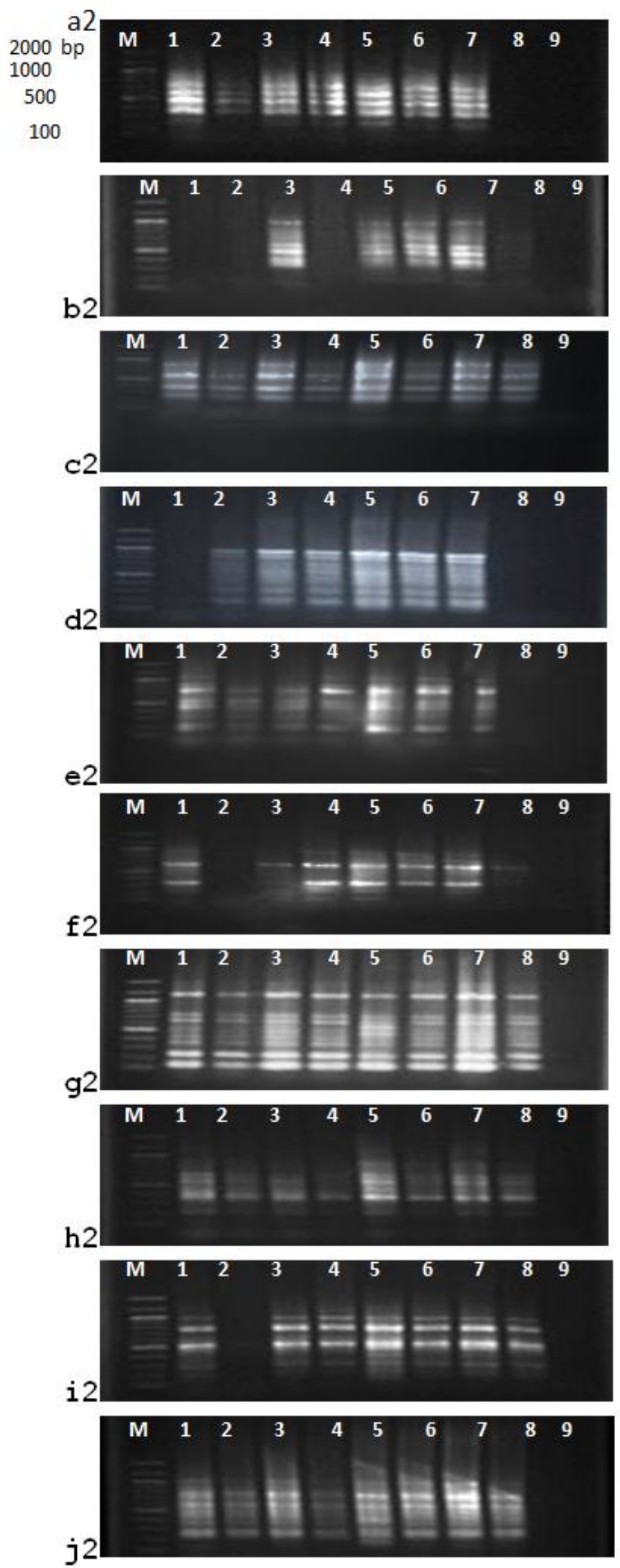

Figure 1: Electrophoretic banding patterns of 10 RAPD primers (a: K02, b: K03, c: K04, d: K06, e: K07, f: K08, g: K10, h: L01, i: M02 and j: M04) after DNA amplification of $a_{1}, b_{1}, c_{1}, d_{1}, e_{1} f_{1}, g_{1}, h_{1}, i_{1}$ and $j_{1}(1-9)$ which indicate to nine cloves of Egased1 clone and $a_{2}, b_{2}, c_{2}, d_{2}, e_{2} f_{2}, g_{2}, h_{2}, i_{2}$ and $j_{2}$ refer to: nine cloves of Balady clone (1-9). M: 100 bp ladder marker. 
RAPD primer. Except sample of lane no.5 of Egased1 and lane no.9 of Balady, all the examined samples successfully generated DNA fragments by using L-01 primer Figure $1\left(\mathbf{h}_{\mathbf{1}}\right.$ and $\left.\mathbf{h}_{\mathbf{2}}\right)$.

The electrophoretic pattern of PCR products generated by the M-02 primer revealed that five DNA polymorphic fragments were produced with different amplicon sizes (139, 188, 395, 672 and 994 bp) as shown in Figure 1 (i $\mathbf{i}_{\mathbf{1}}$ and $\mathbf{i}_{\mathbf{2}}$ ). All samples could generate DNA fragments except clove no. 3 in the third bulb of Balady genotype. Seven polymorphic bands ranged from 150 to 828 bp were produced by using M04 RAPD primer Figure $1\left(\mathbf{j}_{\mathbf{1}}\right.$ and $\left.\mathbf{j}_{\mathbf{2}}\right)$. However, M04 RAPD primer failed to amplify any fragments in sample of lane no. 9 of genotype Balady.

\subsection{SSR markers}

Fifteen SSR primers (Table 2) were deployed to mainly amplify the simple sequence repeats (SSR) DNA regions of the representative eighteen cloves in two garlic genotypes (Balady and Egaseed1). Two primers (Asa14 and Asa24) failed to generate any DNA fragments. A total number of 45 DNA fragments were amplified by using the other 13 SSR primers. Out of them, $12(26.7 \%)$ were monomorphic while the remaining 33 fragments $(73.3 \%)$ were polymorphic including two unique fragments as shown in (Table 4).

As shown in Figure 2 ( $\mathbf{a}_{1}$ and $\mathbf{a}_{2}$ ), primer Asa04 generated two monomorphic bands (195 and $254 \mathrm{bp}$ ), while Asa06 primer amplified only one monomorphic DNA fragment with amplicon size of $109 \mathrm{bp}$ in all cloves but not in lane no. 9 of Balady genotype Figure $2\left(\mathbf{b}_{1}\right.$ and $\left.\mathbf{b}_{2}\right)$. The amplification profile of the Asa07 primer showed only one monomorphic band (224 bp) in almost all examined cloves of the two garlic clones. No amplified fragments were detected from four cloves (lanes 2, 4, 6 and 9) of Balady accession as shown in Figure $2\left(\mathbf{c}_{\mathbf{1}}\right.$ and $\left.\mathbf{c}_{2}\right)$. Two polymorphic DNA fragments (158 and $243 \mathrm{bp}$ ) were formed by using the Asa08 primer Figure $2\left(\mathbf{d}_{\mathbf{1}}\right.$ and $\left.\mathbf{d}_{\mathbf{2}}\right)$.
No DNA fragments were detected from sample number nine of genotype Balady. Moreover, two samples (No. 5 and 9) of the genotype Egased1 and three samples (No. 4, 6 and 9) of Balady generated only the smallest band of $158 \mathrm{bp}$. For Asa10 primer, two polymorphic bands of 181 and $441 \mathrm{bp}$ were observed Figure $2\left(\mathbf{e}_{1}\right.$ and $\left.\mathbf{e}_{2}\right)$. However. Data indicated that no unique bands were observed by using Asa10 primer conferring a $100 \%$ of polymorphism.

Two monomorphic (81 and $134 \mathrm{bp}$ ) and two polymorphic fragments (472 and $759 \mathrm{bp}$ ) with $50 \%$ polymorphism were generated after Asa16 primer application as shown in Figure 2 ( $\mathbf{f}_{\mathbf{1}}$ and $\mathbf{f}_{\mathbf{2}}$ ). In addition, two polymorphic DNA fragments (146 and $379 \mathrm{bp}$ ) were produced from the Asa18 SSR primer Figure $2\left(g_{1}\right.$ and $\left.g_{2}\right)$. Data indicated that only the clove number 1 of the clone Egased1 and number nine of the clone Balady failed to generate any DNA fragments with the Asa18 primer. Five DNA fragments with different sizes ranged from 107 to 459 bp were generated by the Asa20 SSR primer as shown in Figure $2\left(\mathbf{h}_{1}\right.$ and $\mathbf{h}_{\mathbf{2}}$ ). On the other hand, the Asa23 primer amplified four polymorphic DNA fragments $(170,229,416$ and $556 \mathrm{bp})$ as shown in Figure 2 ( $\mathbf{i}_{1}$ and $\mathbf{i}_{2}$ ). Only the sample of clove number (9) of both Egased1 and Balady clones could not generate any DNA fragments by using the Asa23 primer. The samples of cloves number $(2,4,6$ and 8$)$ of clone Balady generated only the two bands (170 and 229).

After applying Asa25 SSR primer, a total number of three amplified fragments were detected Figure 2 ( $\mathbf{j}_{\mathbf{1}}$ and $\left.\mathbf{j}_{2}\right)$. Data confirmed that two bands of them were monomorphic with 116 and $165 \mathrm{bp}$. No unique bands were found and the percentage of polymorphism was $33.3 \%$ (Table 4). The electrophoretic pattern of PCR products generated by the Asa27 SSR primer revealed that seven DNA fragments with different sizes ranged from 90 to 400 bp were found as shown in Figure $2\left(\mathbf{k}_{\mathbf{1}}\right.$ and $\left.\mathbf{k}_{\mathbf{2}}\right)$. Out of them, five fragments were monomorphic with amplicon sizes of 90, 146, 165, 218 and $264 \mathrm{bp}$, while the remaining two fragments were polymorphic with $28.6 \%$.

Table 4: Total number of monomorphic, unique and polymorphic fragments generated by 13 SSR primers in 18 garlic plants.

\begin{tabular}{|c|c|c|c|c|c|c|}
\hline \multirow[b]{2}{*}{ Primers } & \multirow[b]{2}{*}{ Monomorphic bands } & \multirow{2}{*}{$\begin{array}{l}\text { Unique } \\
\text { bands }\end{array}$} & \multicolumn{2}{|c|}{ Polymorphic bands } & \multirow{2}{*}{$\begin{array}{c}\text { Total } \\
\text { number of } \\
\text { bands }\end{array}$} & \multirow[b]{2}{*}{ Polymorphism (\%) } \\
\hline & & & $\begin{array}{l}\text { without } \\
\text { Unique }\end{array}$ & with Unique & & \\
\hline $\mathrm{Asa04}$ & 2 & 0 & 1 & 1 & 3 & 33.33 \\
\hline Asa06 & 0 & 0 & 1 & 1 & 1 & 100 \\
\hline Asa07 & 0 & 1 & 1 & 2 & 2 & 100 \\
\hline Asa08 & 0 & 0 & 2 & 2 & 2 & 100 \\
\hline Asa10 & 0 & 0 & 2 & 2 & 2 & 100 \\
\hline Asa16 & 2 & 0 & 2 & 2 & 4 & 50.0 \\
\hline Asa18 & 0 & 0 & 2 & 2 & 2 & 100 \\
\hline Asa20 & 0 & 0 & 5 & 5 & 5 & 100 \\
\hline Asa23 & 0 & 0 & 4 & 4 & 4 & 100 \\
\hline Asa25 & 2 & 0 & 1 & 1 & 3 & 33.3 \\
\hline Asa27 & 5 & 1 & 1 & 2 & 7 & 28.6 \\
\hline Asa31 & 0 & 0 & 6 & 6 & 6 & 100 \\
\hline Asa59 & 1 & 0 & 4 & 4 & 5 & 85.7 \\
\hline Total & 12 & 2 & 31 & 33 & 45 & 76.74 \\
\hline
\end{tabular}



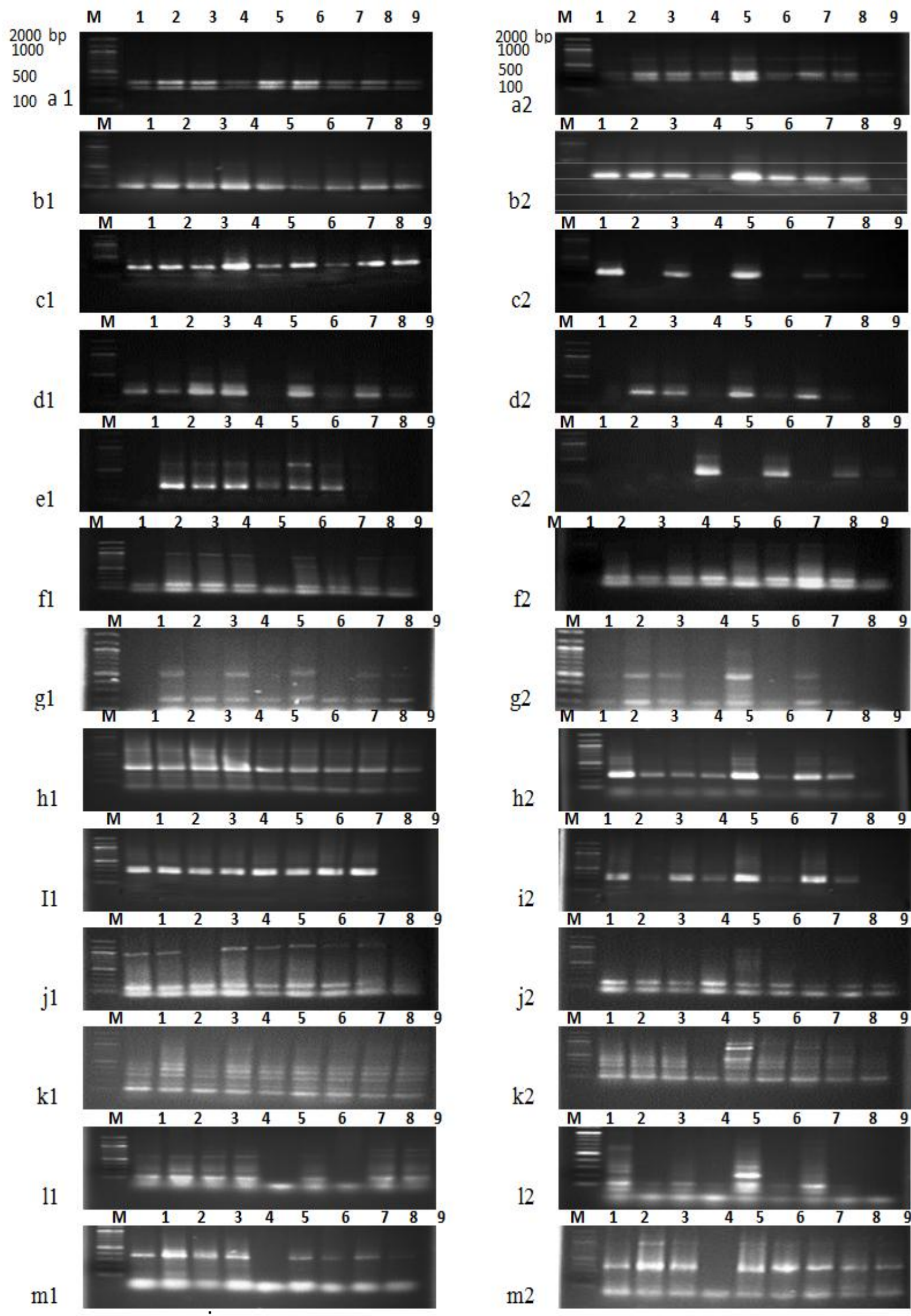

Figure 2: Electrophoretic banding patterns of 13 SSR primers (a: Asa04, b: Asa06, c: Asa07, d: Asa08, e: Asa10, f: Asa16, g: Asa18, h: Asa20, i: Asa23, j Asa25, k: Asa27, 1: Asa31 \& m: Asa59). $a_{1}$ through $m_{1}$ refer to nine cloves (1-9) of Egased1 clone and $a_{2}$ through $m_{2}$ refer to nine cloves of Balady clone. M: 100 bp ladder marker. 
By using the Asa27 SSR primer the DNA fragment of $400 \mathrm{bp}$ was recognized as unique band in the clove sample number 5 of the genotype Balady. Also, the DNA fragment of $322 \mathrm{bp}$ was found only in the samples (No. 5 and 7) of Balady. The Asa31 primer could amplify six DNA fragments ranged from 94 to $1604 \mathrm{bp}$ as shown in Figure $2\left(\mathbf{l}_{\mathbf{1}}\right.$ and $\left.\mathbf{l}_{\mathbf{2}}\right)$. All of them were polymorphic with $100 \%$. This primer could not amplify any DNA fragments in four of all examined samples. Only one band of $155 \mathrm{bp}$ found in samples (No. 2, 4 and 6) of the clone Balady. PCR products of Asa59 primer Figure $2\left(\mathbf{m}_{\mathbf{1}}\right.$ and $\left.\mathbf{m}_{\mathbf{2}}\right)$ were five DNA fragments with different amplicon sizes $(65,118,195$, 273 and $766 \mathrm{bp}$ ). Out of them, four fragments were polymorphic with $85.7 \%$ (Table 4). One fragment with 65 bp was recognized as monomorphic band

\section{Discussion}

Based on two common markers (RAPD and SSR), data reported herein clearly showed the existence of molecular variation between individual cloves derived from the same bulb. The answer of question, how this individual molecular variation comes from, is still crucial. Because of the apomictic nature of garlic reproduction and the accumulation of many changes at the molecular level, the analysis of genetic diversity plays a vital role in breeding programs. The previous studies focused on the sources of variation among garlic clones in the form of bulk samples [1,3,4,6,7,8,16,31-34]. Cytological and molecular events pushed to genetic variation emergence couldn't be accurately determined in bulk plants $[10,35]$. However, the molecular variation between individual cloves might be attributed to the transposition of certain elements like those detected by Helmy and Anwar [36]. Some minute chromosomal aberrations like those observed by El-Mamlouk et al., [3]; Ata [4]; Osman et al. [6]; Ata and Osman[7]; Anwar and Ata[8] and Anwar et al. [16], may occurred periodically during bulb storage in the time of dormancy. Therefore, different molecular techniques could be used to evaluate diversity and confirm the differences between the cloves within the same bulb and the differentiated nature of garlic. In addition, it defines the importance of using molecular markers to evaluate different garlic clones. Likewise, several studies including molecular events, proteomics and transcriptomics that may share in interpretation the unbelievable appearance of physiological, genetical and epigenetical variations on the cellular, tissue, and clove levels in garlic should be carried out.

\section{Conclusion}

Genetic diversity and the sources of molecular variation between the individual cloves of two garlic clones were studied by using two different molecular markers (RAPD and SSR). Data reported evidently showed the presence of molecular variation between individual cloves derived from the same bulb. Therefore, different molecular techniques and several studies including molecular events, proteomics and transcriptomics that may share in interpretation the unbelievable appearance of physiological, genetical and epigenetical variation on the cellular, tissue, and clove levels in garlic.

\section{References}

[1] Ipek, M., Ipek, A., Almquist, S. G. and Simon, P.W. Demonstration of linkage and development of the first low density genetic map of garlic, based on AFLP markers. Theor. Appl. Genet., 2005, 110, 228-236.

[2] Sun, X., Zhou, S., Meng, F. and Liu, S., De novo assembly and characterization of the garlic (Allium sativum) bud transcriptome by Illumina sequencing. Plant cell reports, 2012, 31(10), 1823-1828.

[3] El-Mamlouk, E. A-K., Ata, A. M., Mahmoud, M. A-H., Foly, H. M. and Allam, H. Z. Cytological features and isozymes profile of some Allium sativum L. (garlic) genotypes cultivated in Egypt. Minia Journal of Agricultural Research and Development 2002, 22: 1420-1440.

[4] Ata, A. M. Constitutive heterochromatin diversification of two Allium species cultivated in Egypt. Proc. Afr. crop sci. conf. 2005, 7: 225-231.

[5] Buso, G. S. C., Paiva, M. R., Torres, A. C., Resende, F. V., Ferreira, M. A., Buso, J. A. and Dusi, A. N. Genetic diversity studies of Brazilian garlic cultivars and quality control of garlic-clover production. Genetics and Molecular Research, 2008,7(2), 534-541

[6] Osman, S. A., Ata, A. M. and Gad, El-Hak S. E. Morphological germination bolting and cytogenetical characteristics of fourteen promising garlic genotypes. Proc. Afr. Crop Sci. Conf. 2007, 8: 2005-2012.

[7] Ata, A. M. and Osman, S. A., Gametogenesis of Two Garlic Clones Selected from Egyptian Indigenous Forms. African Crop Science Conference Proceedings 2009, 9: 483-487.

[8] Anwar, G. M. and Ata, A. M. Chromosome association of two flowering garlic clones. Indian Journal of plant Sciences 2017, 6(2): 52-58.

[9] Anwar G.M., Helmey R. K. and Mostafa Y. M. Genetic diversity among some species of the genus Allium L. Using SSR and ISSR markers. Egypt. J. Genet. Cytol. 2017, (46):221-233.

[10] Mahmoud, M. A-H, Ata, A. M., Tawfeek, A-R., Dakhly, O. F. And Gehan M. A. studies of some cytological features of garlic (Allium sativum 1.) Clones cultivated in egypt. Egypt. J. Plant Breed. 2017, 21(5):800-819.

[11] Maß, H. I. and Klaas, M. Infraspecific differentiation of garlic (Allium sativum L.) by isozyme and RAPD markers. Theoretical and Applied Genetics, 1995, 91(1), 89-97

[12] Bachmann, K. F., Blattner, D., Fischer, N., Freisen, R., Fritsch, M., Klaas, T. Mes. and Pollner, S. Molecular markers in: range of application, reliability and taxonomic implications. Acta Hort., 2001, 546: 159-163.

[13] Williams, J. G., Kubelik, A. R.; Livak, K. J., Rafalski, J. A. and Tingey, S. V., DNA polymorphisms amplified by arbitrary primers are useful as genetic markers. Nucleic acids research, 1990, 18(22), 6531-6535.

[14] Jo, M.H., Ham, I.K., Moe, K.T., Kwon, S-W., Lu, F-H., Park, Y-J., Kim, W.S., Won, M.K., Kim, T.I. and Lee, E.M., Classification of genetic variation in garlic (Allium sativum L) using SSR markers. Australian Journal of Crop Science, 2012, 6(4):625-631.

[15] Chen S., Chen W., Shen X., Yang Y., Qi F., Liu Y. and Meng H., Analysis of the genetic diversity of garlic (Allium sativum L.) by simple sequence repeat and inter simple sequence repeat analysis and agro-morphological traits. Biochemical Systematics and Ecology 2014, (55): 260-267.

[16] Anwar G.M., Helmey R. K. and Mostafa Y. M. Assesment of genetic diversity in garlic clones using SSR and ISSR markers. Egypt. J. Genet. Cytol. 2016, (45):333-345.

[17] Barboza, K., Beretta, V., Kozub, P. C., Salinas, C.,Morgenfeld, M. M. Galmarini, C. R., and Cavagnaro, P. F. Microsatellite analysis and marker development in garlic: distribution in EST sequence, genetic diversity analysis, and marker transferability across Alliaceae. Molecular genetics and genomics, 2018, 293(5), 1091-1106.

[18] Vos, P., Hogers, R., Bleeker, M., Reijans, M., Lee, T. V. D., Hornes, M and Zabeau, M. AFLP: a new technique for DNA fingerprinting. Nucleic acids research, 1995, 23(21), 4407-4414.

[19] Ipek, M and Simon, P.W. Evaluation of genetic diversity among garlic clones using molecular markers: comparison of AFLPS, RAPD and isozyme. Plant \& Animal Genome X Meeting, 2002, January 12-16.

[20] Zietkiewicz, E., Rafalski, A. and Labuda, D., Genome fingerprinting by simple sequence repeats (SSR) anchored polymerase chain reaction amplification. Genomics, 1994, 20,176-183.

[21] Castiglione, S., Wang, G., Damiani, G., Bandi, C., Bisoffi, S. and Sala, F. RAPD fingerprints for identification and for taxonomic studies of elite poplar (Populus spp.) clones. Theoretical and Applied Genetics, 1993, 87(1-2), 54-59.

[22] Corniquel, B. and Mercier, L. Date palm (Phoenix dactylifera L.) cultivar identification by RFLP and RAPD. Plant Science, 1994, 101(2), 163-172.

[23] Chunwongse, J., Martin, G. B. and Tanksley, S. D. Pre-germination genotypic screening using PCR amplification of half-seeds. Theoretical and applied genetics, 1993, 86(6), 694-698 
[24] Taylor, S. and Todd, P. A. Understanding information technology usage: A test of competing models. Information systems research, 1995, 6(2), 144-176.

[25] Chen, H.W., Fu, M.Y., Hsieh, M.R., Tasi, T.W., Chyou, S.M., Wu, C.C. and Lin, S.Y. Application of DNA fingerprinting in the breeding of Phalaenopsis orchid, in Terzi, M., Cella, R. And Falavigna, A. (eds), in Current Plant Science and Biotechnology in Agriculture, Kluwer, Academic Press, Netherland, 1995.

[26] Sambrook, J., Fritsch, E.F. and Maniatis, T. Molecular cloning: A Laboratory Manual. Cold Spring Harbor, New York: Cold Spring Harbor Laboratory Press, 1989.

[27] Anwar G. M. Genetical and Molecular studies on some garlic clones. Ph.D. thesis, Faculty of Agriculture, Minia University, Egypt, 2011.

[28] Cunha, C. P., Hoogerheide E. S. S., Zucchi, M. I., Monteiro M. and Pinheiro J. B., New microsatellite markers for garlic, (Alliaceae). American Journal of Botany, 2012, 99: e17-e19.

[29] Ma, K. H., Kwag, J. G., Zhao, W., Dixit, A., Lee, G. A., Kim, H. H., Chung, I. M., Kim N. S.; Lee, J. S., Ji, J. J., Kim, T. S. and Park, Y. J., Isolation and characteristics of eight novel polymorphic microsatellite loci from the genome of garlic (Allium sativum L.). Hort. Sci., 2009, 122: 355-361.

[30] GelAnalyzer, Version three, Gel Analyzer Ver.3 program software for windows, 2007.

[31] Ipek, M., Ipek, A. and Simon, P. W. Comparison of AFLPs, RAPD markers, and isozymes for diversity assessment of garlic and detection of putative duplicates in germplasm collections. Journal of the American Society for Horticultural Science, 2003, 128(2), 246-252.

[32] İpek, M., İpek, A. and Simon, P. W. Rapid characterization of garlic clones with locus-specific DNA markers. Turkish Journal of Agriculture and Forestry, 2008, 32(5), 357-362.

[33] Lampasona, G.S., Martinez, L. and Burba, J.L. Genetic diversity among selected Argentinean garlic clones ( Allium sativum L.) using AFLP (amplified fragment length polymorphism). Euphytica, 2003, 132, 115-119.

[34] Volk, G. M., Henk, A. D. and Richards, C. M. Genetic diversity among US garlic clones as detected using AFLP methods. Journal of the American Society for Horticultural Science, 2004, 129(4), 559-569.

[35] Anwar, G. M., Ata, A. M., Mahmoud, M. A-H., Tawfeek, A-R. and Dakhly, O. F. Morphological and biochemical assessment of sixteen garlic clones cultivated in Egypt. Egypt. J. Plant Breed, 2017, 21(5):820-836.

[36] Helmy, R.K. and Anwar, G.M. Chromosomal aberrations and Ac/Ds transposition in Garlic. Chromosome Botany, 2018, 12(4): 72-76. 